\title{
The Differential Effects of a Selective Kappa-Opioid Receptor Agonist, U50488, in Guinea Pig Heart Tissues
}

\author{
Chi-Feng Hung, ${ }^{1,2}$ Hsin-Ju Li, ${ }^{3}$ Hsun-Hao Chang, ${ }^{4}$ Gon-Ann Lee, ${ }^{3}$ and Ming Jai Su ${ }^{5}$ \\ ${ }^{1}$ School of Medicine, Fu Jen Catholic University, No. 510 Zhongzheng Road, Xinzhuang District, New Taipei City 24205, Taiwan \\ ${ }^{2}$ Big Data Research Centre, Fu Jen Catholic University, New Taipei City, Taiwan \\ ${ }^{3}$ Department of Chemistry, Fu Jen Catholic University, New Taipei City, Taiwan \\ ${ }^{4}$ Department of Cardiology, Tainan Municipal Hospital, No. 670 Chongde Road, East District, Tainan 70173, Taiwan \\ ${ }^{5}$ Department of Pharmacology, College of Medicine, National Taiwan University, No. 1 Jen-Ai Road, Section 1, Zhongzheng District, \\ Taipei 10051, Taiwan
}

Correspondence should be addressed to Chi-Feng Hung; 054317@mail.fju.edu.tw

Received 11 July 2014; Revised 2 November 2014; Accepted 4 November 2014

Academic Editor: Adair Santos

Copyright ( 2015 Chi-Feng Hung et al. This is an open access article distributed under the Creative Commons Attribution License, which permits unrestricted use, distribution, and reproduction in any medium, provided the original work is properly cited.

\begin{abstract}
The differential effects of a selective kappa- $(\kappa-)$ opioid receptor agonist, U50488, were elucidated by monitoring the contraction of isolated guinea pig atrial and ventricular muscles. In electrically driven left atria, U50488 in nanomolar concentration range decreased the contractile force. Norbinaltorphimine (norBNI), a selective $\kappa$-receptor antagonist, and pertussis toxin (PTX) abolished the negative inotropic effect of U50488. In contrast, the inhibitory effect was not affected by the pretreatment of atropine or propranolol. Even though U50488 exerted a negative inotropic effect in the left atrium, it did not affect the contractile force of the right atrium and ventricles paced at $2 \mathrm{~Hz}$. Similarly, the beating rate of the spontaneously beating right atrium was also unaffected

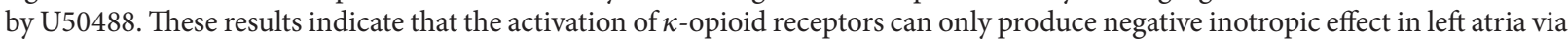
activation of PTX-sensitive G protein in guinea pigs. The absence of negative inotropic effects in right atria and ventricles suggests that there may be a greater distribution of functional $\kappa$-opioid receptors in guinea pig left atria than in right atria and ventricles, and the distribution of the receptors may be species-specific.
\end{abstract}

\section{Introduction}

Many studies have indicated that $\kappa$-opioid receptors exist in the heart by receptor binding assay [1-3] and physiological studies $[4,5]$. Stimulation of $\kappa$-opioid receptors in the heart may evoke negative inotropic $[6,7]$ and chronotropic effects [8]. Prior investigators also suggested that activation of cardiac $\kappa$-opioid receptors could mediate cardioprotective and antiarrhythmic effect during myocardial ischemia and reperfusion [9-12]; modulation of cardiac function by opioid peptide receptor agonists or antagonists, and future drug development to improve myocardial salvage would be possible $[2,3]$.

While U50488, a selective $\kappa$-opioid receptor agonist, decreases the electrically induced $\left[\mathrm{Ca}^{2+}\right]_{\mathrm{i}}$ transient in rat cardiac myocytes at a higher concentration $(\mu \mathrm{mol} / \mathrm{L})$ by activating the phosphoinositol pathway $[13,14]$, it inhibits the augmentation of the electrically induced $\left[\mathrm{Ca}^{2+}\right]_{\mathrm{i}}$ transient by $\beta$-adrenoceptor stimulation in the heart at a lower concentration $(\mathrm{nmol} / \mathrm{L})$ [13]. Electrophysiological studies showed that U50488 could inhibit the P-type calcium channel in brain Purkinje cells through activation of $\kappa$-opioid receptors $[15,16]$; it could also inhibit the L-type calcium, sodium, and potassium channels in ventricular myocytes directly at a higher concentration $[17,18]$.

Several studies have reported that 5-hydroxytryptamine (5-HT), calcitonin gene-related peptide (CGRP), angiotensin II, somatostatin, adenosine, and diadenosine tetraphosphate changed the contractile force more in atrial than in ventricular tissues [19-23]. However, opioid receptors exist in both atria and ventricles; it is still unknown whether there is any response difference in the $\kappa$-opioid receptors between these 


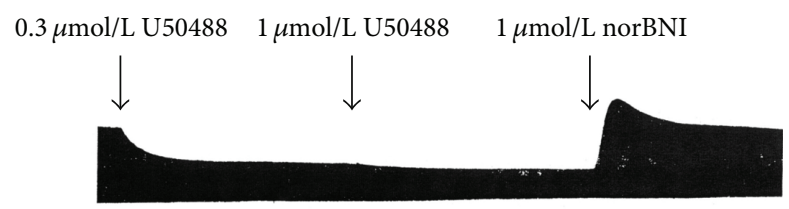

(a) Left atrium

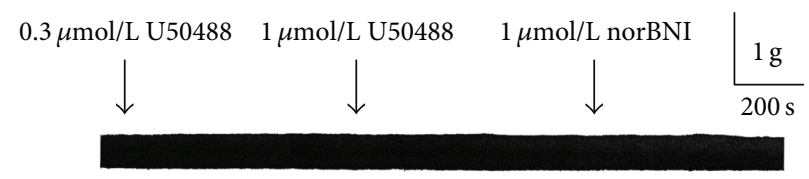

(b) Right atrium

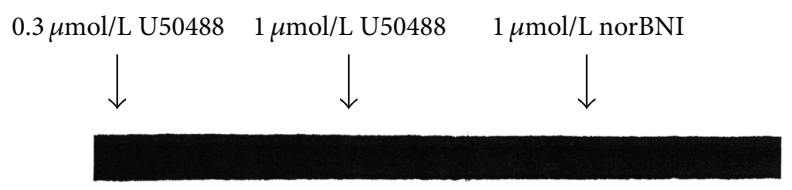

(c) Right ventricle

FIGURE 1: Effect of U50488 on the contractile force in guinea pig atria and ventricle. Sinoatrial node of right atrium was removed. Atria and ventricle were paced at $2 \mathrm{~Hz}$. After equilibrium for $30 \mathrm{~min}$, U50488 and norBNI were added sequentially. (a) Left atrium. (b) Right atrium. (c) Right ventricle.

tissues. This study was planned to examine the effects of a selective $\kappa$-receptor agonist, U50488, on atrial and ventricular muscles isolated from guinea pigs.

\section{Materials and Methods}

2.1. Chemicals. NorBNI (norbinaltorphimine), U50488 (trans-3,4-dichloro-N-methyl-N-[2-(1-pyrrolidinyl)cyclohexyl]-benzeneacetamide), U69593 ((+)- $(5 \alpha, 7 \alpha, 8 \beta)$-N-methyl-N-[7-(1-pyrrolidinyl)-1-oxaspiro[4.5]dec-8-yl]-benzeneacetamide), and PTX (pertussis toxin) were purchased from Research Biochemicals International (RBI) Chem. Co. (USA). Propranolol, atropine, and carbachol were purchased from Sigma Chem. Co. (USA).

2.2. Isolated Cardiac Preparations and Mechanical Response. Preparations of isolated left and right atria (or ventricles) from male guinea pigs (Hartley strain, $0.2-0.5 \mathrm{~kg}$ ) were used. The preparations were bathed in Tyrode solution, and the Tyrode solution (composition in $\mathrm{mM}$ : $\mathrm{NaCl} 137.0, \mathrm{KCl} 5.4$, $\mathrm{MgCl}_{2} 1.1, \mathrm{NaHCO}_{3} 11.9, \mathrm{NaH}_{2} \mathrm{PO}_{4}$ 0.33, dextrose 11.0, and $\mathrm{CaCl}_{2}$ 1.8) was aerated with $5 \% \mathrm{CO}_{2}$ and $95 \% \mathrm{O}_{2}$ at $37 \pm$ $0.5^{\circ} \mathrm{C}$. Contractions of spontaneously beating right atrial preparations, as well as the electrically driven left atrial, right atrial, and right ventricular strips, were measured by connecting one end of the preparation to a force displacement transducer (type BG 25, Gould Inc., Cleveland, Ohio, USA) by a fine silk thread and were recorded on a Gould RS 3400 recorder. To obtain the maximum developed tension, an optimal preload $(1.0 \mathrm{~g})$ was used. Left atria, right atria, and right ventricular strips were stimulated at a frequency of $2 \mathrm{~Hz}$ by rectangular pulse of $2 \mathrm{~ms}$ duration at supramaximal intensity via an isolated Grass S88 stimulator (Grass Instruments Co., Quincy, MA, USA).
2.3. Assessment of the Effects of PTX. To assess a possible role of pertussis toxin-sensitive $G$ protein in the actions of U50488, guinea pigs were pretreated with PTX $150 \mu \mathrm{g} / \mathrm{kg}$ (i.p.) for $24 \mathrm{~h}$ before sacrifice. The influence of PTX on cardiac tissues was verified by the contractile responses of left atrial strips to carbachol. Carbachol $(0.1 \mu \mathrm{mol} / \mathrm{L})$ decreased the basal contractile force from $0.8 \pm 0.1 \mathrm{~g}$ to $0.5 \pm 0.1 \mathrm{~g}$ (decrease about $44 \%$ in control group, $n=5$ ), whereas a less decrease was found, from $0.8 \pm 0.1 \mathrm{~g}$ to $0.6 \pm 0.1 \mathrm{~g}$ (decrease about $24 \%$, $n=5$ ), in PTX-treated group.

2.4. Statistics. Data are expressed as mean \pm SE. Statistics comparison was made by Student's paired or unpaired $t$-test with the level of significance taken as $P<0.05$.

\section{Results}

3.1. The Differential Effects of $\kappa$ Receptor Agonists on Cardiac Contractility. Figure 1 shows the original tracings of continuous tension recordings of three different guinea pig atrial and ventricular preparations in cumulative response to $300 \mathrm{nmol} / \mathrm{L}$ and $1 \mu \mathrm{mol} / \mathrm{L}$ U50488. In the left atrium, U50488 exerted a significant and immediate negative inotropic effect (Figure 1(a)). This inhibitory effect reached a steady state in $10 \mathrm{~min}$ and could be eliminated by norBNI $(1 \mu \mathrm{mol} / \mathrm{L})$, a selective $\kappa$-opioid receptor antagonist. In contrast, the inhibitory effect was not found in the preparations of right atrium, right ventricle (Figures 1(b) and 1(c)), and left ventricle (not shown). Average data of the influence of U50488 on the contractile force of left atrial preparations are shown in Figure 2. U50488 started to reduce the contractile force significantly at $30 \mathrm{nmol} / \mathrm{L}$. At $100 \mathrm{nmol} / \mathrm{L}, 300 \mathrm{nmol} / \mathrm{L}$, and $1 \mu \mathrm{mol} / \mathrm{L}$, it reduced the force to $77.3 \pm 5.0 \%, 60.6 \pm 7.7 \%$, and $49.8 \pm 6.9 \%(n=5)$ of the control, respectively. Similarly, 


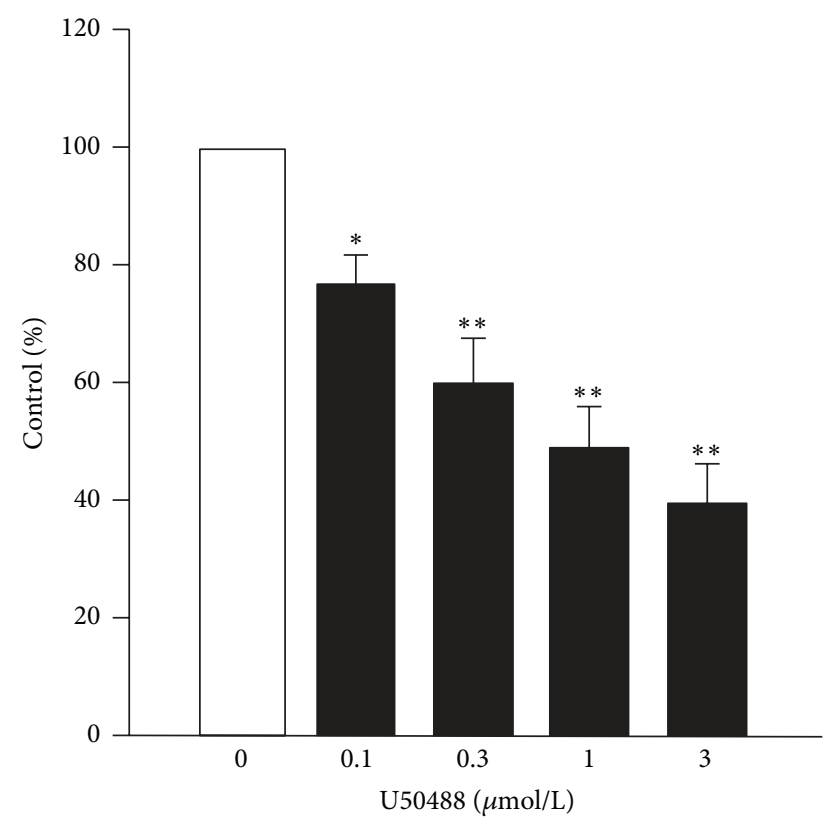

FIGURE 2: The concentration-dependent effects of U50488 on contractile force of left atrium illustrated as percentage of control. Vertical lines are SE. $*$ and $* *$ indicate $P<0.05$ and $P<0.01$ as compared with control $(n=5)$.

we found that U69593, another selective $\kappa$-receptor agonist, also has the same negative inotropic effect on left atria but not the preparations of right atria and ventricles (figure not shown) in our other experiments. The inhibitory effect could also be abolished by norBNI $(1 \mu \mathrm{mol} / \mathrm{L})$. At $300 \mathrm{nmol} / \mathrm{L}$ and $1 \mu \mathrm{mol} / \mathrm{L}$, it reduced the force to $54.4 \pm 5.3 \%$ and $45.9 \pm 6.4 \%$ $(n=4)$ of the control, respectively. As higher concentrations of U50488 and U69593 may elicit effects not mediated via opioid receptor [24], they were not investigated with the $\kappa$ opioid receptor antagonist.

3.2. Effects of norBNI and PTX on the Negative Inotropic Action of U50488. To further evaluate whether the inhibitory effects of U50488 on left atria were due to $\kappa$-opioid receptors and the coupling of inhibitory $G$ protein, $G_{i / o}$, the muscle strips were pretreated with a selective $\kappa_{2}$-receptor antagonist, norBNI $(1 \mu \mathrm{mol} / \mathrm{L})$, for $10 \mathrm{~min}$. We found that norBNI at $1 \mu \mathrm{M}$ alone did not affect the contractile force of the left atrial preparations, but it prevented the inhibitory effects of U50488 (Figure 3(a)). In left atria isolated from guinea pigs pretreated with PTX $(150 \mu \mathrm{g} / \mathrm{kg}$, i.p.), which catalyzes the adenine nucleotide ribosylation of $\mathrm{G}_{\mathrm{i} / \mathrm{o}}$ protein $\alpha$-subunits, U50488 also failed to exert any inhibitory response (Figure 3(b)). The average data of U50488 after norBNI or PTX pretreatment are shown in Figure 4.

\subsection{Effects of Propranolol and Atropine on the Negative Ino-} tropic Action of U50488. It had been reported that propranolol could modify the inhibitory effect of U50488 in isolated right atria of rat $[4,7]$, and the $\kappa$-receptor agonist could inhibit norepinephrine release from cardiac sympathetic

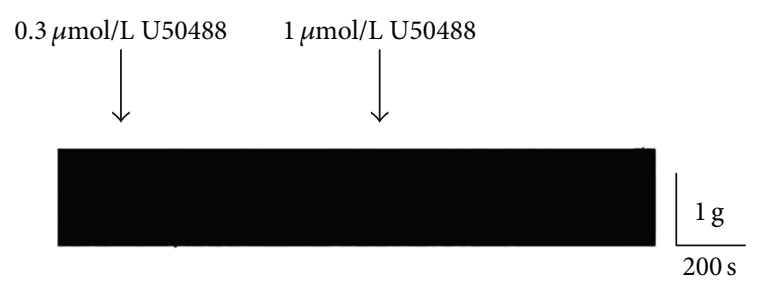

(a) norBNI pretreatment

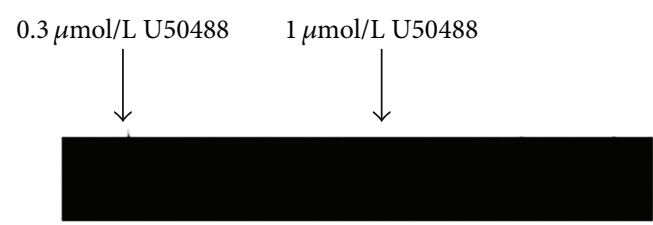

(b) PTX $150 \mu \mathrm{g} / \mathrm{kg}$, i.p.

FIGURE 3: Representative tracings show the effect of norBNI and PTX on the effect of U50488 in left atria. (a) A norBNI $(1 \mu \mathrm{mol} / \mathrm{L})$ pretreated atrium. (b) An atrium from PTX-pretreated guinea pig $(150 \mu \mathrm{g} / \mathrm{kg}$ for $24 \mathrm{~h})$.

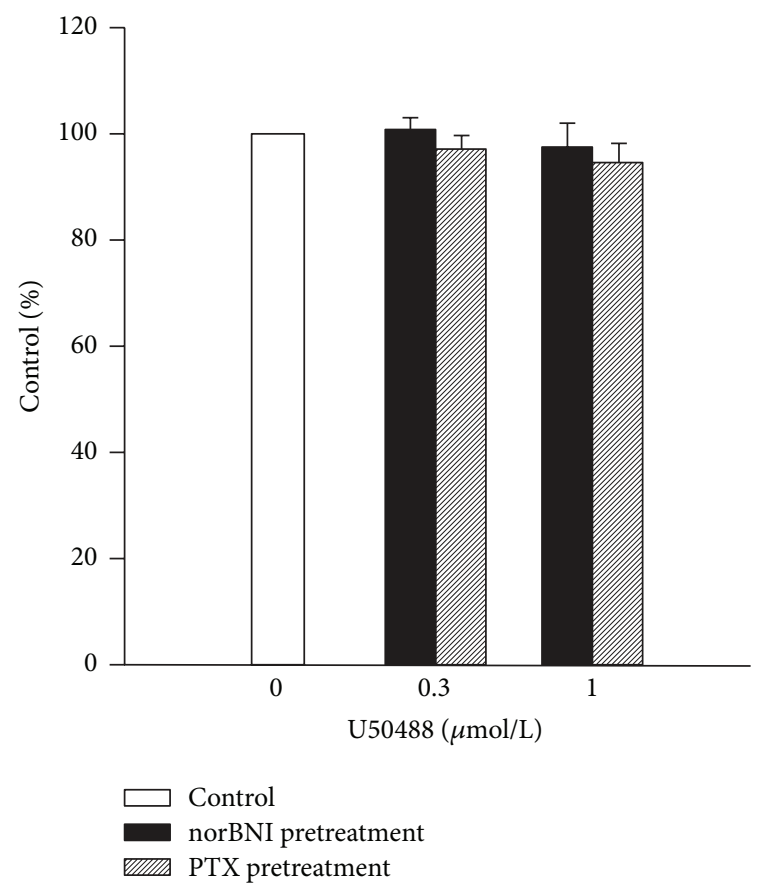

FIGURE 4: Effect of U50488 on left atria pretreated with norBNI $(n=$ $4)$ and PTX $(n=5)$.

nerve [25]. Therefore, we evaluated whether the inhibitory effects of U50488 in isolated left atria of guinea pig could be affected by propranolol $(3 \mu \mathrm{mol} / \mathrm{L})$. A representative example of the effect of propranolol pretreatment on the U50488induced negative inotropic action is shown in Figure 5(a), and the average result is shown in Figure 5(b). The average amplitudes of the contractile force of the left atrial preparations were decreased to $62.7 \pm 4.3 \%, 54.2 \pm 5.1 \%$, and $46.0 \pm$ $5.7 \%(n=6)$ of the control by $0.3,1$, and $3 \mu \mathrm{mol} / \mathrm{L}$ of U50488, respectively. Decreases in contractile force induced by 0.3 


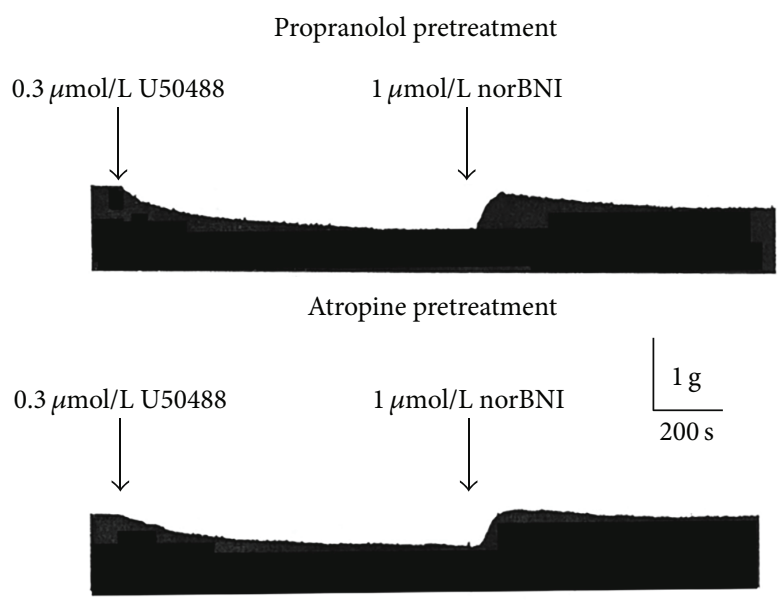

(a)

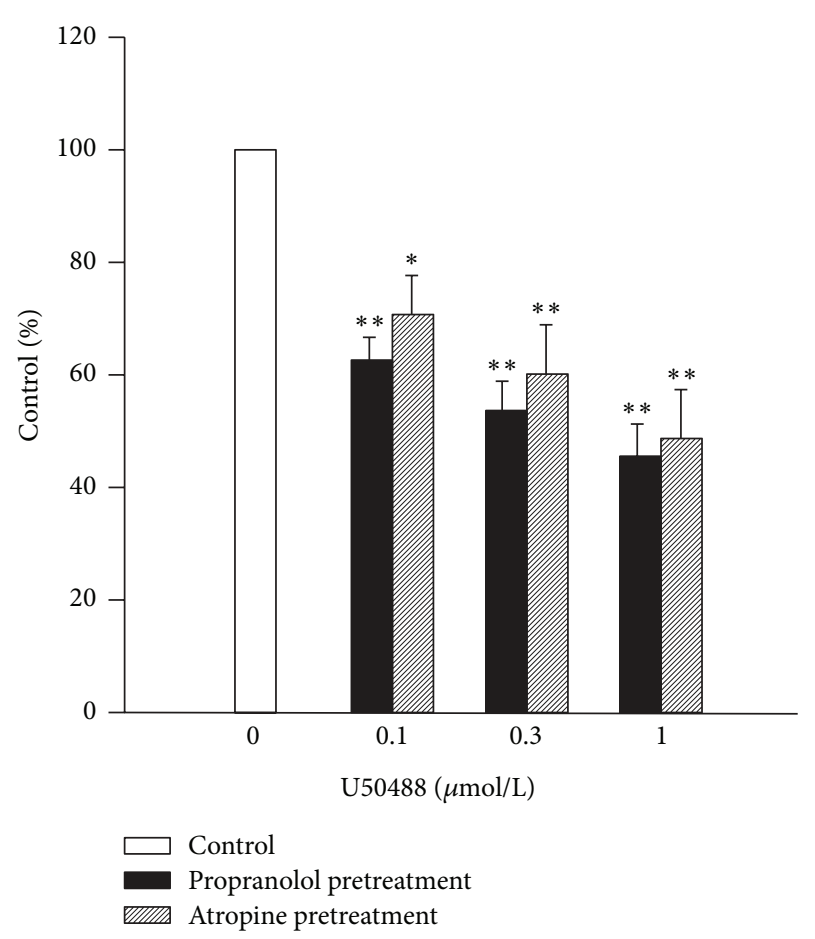

(b)

FIGURE 5: Negative inotropic effect of U50488 in left atria pretreated with propranolol $(3 \mu \mathrm{mol} / \mathrm{L}, n=6)$ or atropine $(1 \mu \mathrm{mol} / \mathrm{L}, n=5)$. (a) Representative traces show the effect of U50488 on the contractile force in left atria pretreated with propranolol or atropine for 20 min. (b) Concentration-dependent effects of U50488 on contractile of left atria in the presence of propranolol or atropine. Values are expressed as percentage of control. Vertical lines are SE. $*$ and $* *$ indicate $P<0.05$ and $P<0.01$ as compared with control.

and $1 \mu \mathrm{mol} / \mathrm{L}$ of U50488 were also completely eliminated by norBNI. In comparison with the decrease in contractile force induced by U50488 alone, propranolol did not affect the negative inotropic effect of U50488 on left atrial preparations. Considering the release of acetylcholine being another possibility which may contribute to the negative inotropic effect of U50488, we examined the negative inotropic effect of U50488 on left atria pretreated with atropine $(1 \mu \mathrm{mol} / \mathrm{L})$. Our data showed that the negative inotropic effect of U50488 was unaffected by atropine. The average amplitudes in contractile force were decreased to $70.6 \pm 7.0 \%, 60.4 \pm 8.6 \%$, and $49.0 \pm 8.6 \%(n=5)$ of the control by $0.3,1$, and $3 \mu \mathrm{mol} / \mathrm{L}$ of U50488, respectively (Figures 5(a) and 5(b)).

3.4. Effect of U50488 on the Spontaneous Beating Rate of Guinea Pig Right Atria. U50488 could evoke negative chronotropic effect on isolated right atria of rat $[6,7]$. However, we did not find any change in the spontaneous beating rate in guinea pig right atria in our study (Figure 6).

\section{Discussion}

In this study, we compared the inotropic effects of U50488 and U69593, two selective $\kappa$-opioid receptor agonists, in guinea pig left atria to their effects in right atria and ventricles. We observed that both U50488 and U69593 dosedependently decreased the contractile force of guinea pig atrial muscles, and this effect was exerted only in left atria. The absence of negative inotropic effect in right atria and ventricles suggests that $\kappa$-opioid receptors in these two regions may be less or absent in guinea pigs. However, missing signaling pathway for coupling of $\kappa$-opioid receptor activation to negative inotropism in these two cardiac tissues may also be another possibility. These speculations remain for further identification, and radioligand binding studies using appropriate radioligands may be necessary.

Corresponding to previous observations which showed the coupling of the $\kappa$-opioid receptor to activation of the $G_{i / o}$ protein [16], our results showed that the negative inotropic effect of U50488 on left atrial tissues could be abolished by norBNI and PTX, which suggests that the action is mediated through $\kappa$-opioid receptors by activation of PTXsensitive $G$ protein. At a higher concentration $(3 \mu \mathrm{mol} / \mathrm{L})$, U50488 was found to decrease the contractile force of right ventricular preparations that could not be eliminated by norBNI in this study. The negative inotropic effect at the higher concentration of U50488 may be due to its directly inhibitory effect instead of the activation of $\kappa$-opioid receptors. These observations agree with the study that showed a direct inhibition of calcium current in guinea pig ventricular myocytes by U50488 at similar concentration range [24]. The $15.0 \pm 4.0 \%(n=6)$ inhibition of the contractile force of right ventricular strips by $3 \mu \mathrm{M}$ U50488 in our study is comparable to the $18 \%$ inhibition of calcium current in guinea pig ventricular cell by Utz et al. [24]. 


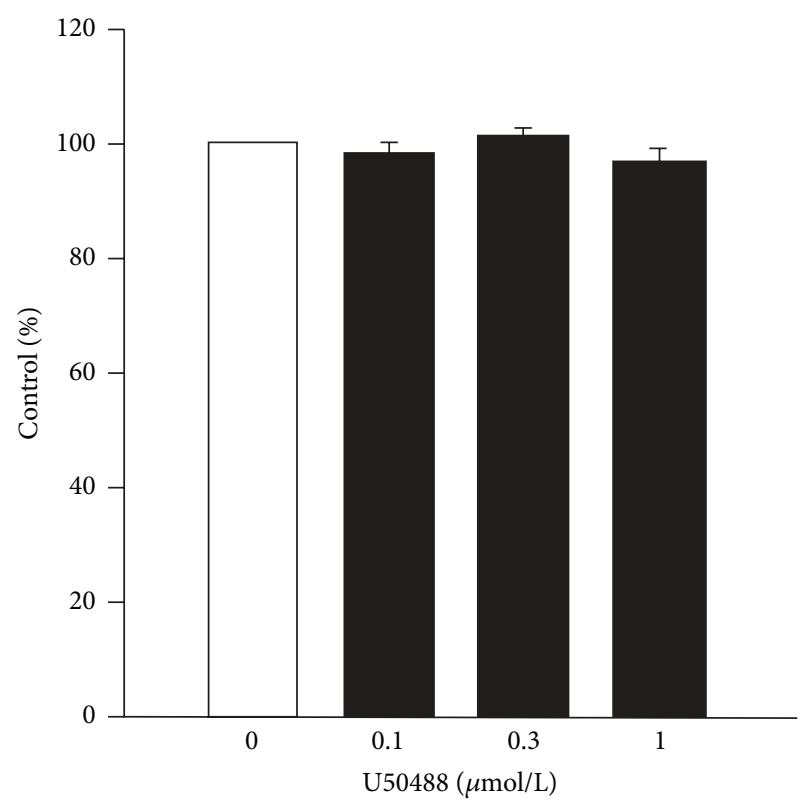

FIGURE 6: Effect of U50488 on spontaneously beating rate of right atria in guinea pig. Values are presented as percentages of control $(n=6)$.

Previously, U50488 had been shown to exert negative inotropic effects in both atrial and ventricular preparations by the activation of $\kappa$ receptors in rats [7]. The different results in this study may be due to the difference in experimental conditions or animal model. In addition, Niroomand et al. [26] have shown that functional $\kappa$-opioid receptors may not present in canine cardiac sarcolemma because the $\kappa$-receptor agonist, U50488, did not inhibit adenylate cyclase activities. These observations strongly suggest that the distribution of $\kappa$-opioid receptors in cardiac myocardium may be speciesspecific. Therefore, functional study of the $\kappa$-opioid receptor on human cardiac preparation is necessary.

In general, agents and interventions that increase $\mathrm{K}^{+}$ conductance $\left(G_{k}\right)$ shorten action potential duration (APD) and tend to have negative inotropic effects, whereas agents that decrease $\mathrm{K}^{+}$current lengthen APD and may have positive inotropic effects [27]. Therefore, the shortening of the action potential duration is a possible mechanism responsible for the negative inotropic effect of U50488. In our unpublished data, we found that U50488 could shorten the duration of action potential and decrease the contractile force in guinea pig left atrial preparations. This effect could also be eliminated by the selective $\kappa$-opioid receptor antagonist, norBNI $(1 \mu \mathrm{mol} / \mathrm{L})$. Because the delayed rectifier and inward rectifier potassium channels play a key role during repolarization of action potential in guinea pig [28-30], the shortening of action potential may be related to these channels being affected by U50488. However, further voltage clamp studies will be needed to characterize the effect of U50488 on the delayed rectifier or inward rectifier potassium current.

To our knowledge this report demonstrates for the first time that the opioid receptor agonist elicits a negative inotropic response in left atria without having a corresponding effect in right atria and ventricles. Whether the different effects of U50488 exist in human tissues remains to be studied. Several studies have shown that postischemic contractile dysfunction or "stunning of myocardium" occurred especially during ischemia-reperfusion [31-33]. During a period of stunning, left ventricular ejection fraction may be significantly impaired. Myocardial stunning may delay recovery from cardiogenic shock or left ventricular failure. Therefore, it is important to avoid stunning of ventricular tissue during ischemia-reperfusion. While there is an increase in $\kappa$-opioid peptide release in myocardial ischemia-reperfusion [34], the absence of significant negative inotropic properties of $\kappa$ opioid receptor agonist in the right ventricle may be beneficial to cardiac performance during ischemia-reperfusion. In addition, decrease in contractile force in the left atrium may slightly alleviate the loading of the left ventricle and be beneficial to the failing left ventricular myocardium.

\section{Conflict of Interests}

The authors declare that there is no conflict of interests regarding the publication of this paper.

\section{Acknowledgments}

This work was supported by a research grant from the National Science Council and Fu Jen Catholic University of Taiwan.

\section{References}

[1] P. Sobanski, M. Krajnik, M. Shaqura, E. Bloch-Boguslawska, M. Schäfer, and S. A. Mousa, "The presence of mu-, delta-, and kappa-opioid receptors in human heart tissue," Heart and Vessels, vol. 29, no. 6, pp. 855-863, 2014.

[2] K. Tanaka, J. R. Kersten, and M. L. Riess, "Opioid-induced cardioprotection," Current Pharmaceutical Design, vol. 20, no. 36, pp. 5696-5705, 2014.

[3] M. M. Theisen, S. Schlottmann, C. August et al., "Detection and distribution of opioid peptide receptors in porcine myocardial tissue," Pharmacological Research, vol. 84, pp. 45-49, 2014.

[4] T. V. Lasukova, L. N. Maslov, S. W. Nizkodubova, A. S. Gorbunov, and S. Y. Zibulnikov, "Role of intracellular calcium and cyclic nucleotides in realization of cardioprotective effects of $\delta_{1}$ - and $\kappa_{1}$-Opioid receptor agonists," Bulletin of Experimental Biology and Medicine, vol. 148, no. 6, pp. 877-880, 2009.

[5] L.-W. Fu and J. C. Longhurst, "Functional role of peripheral opioid receptors in the regulation of cardiac spinal afferent nerve activity during myocardial ischemia," American Journal of Physiology: Heart and Circulatory Physiology, vol. 305, no. 1, pp. H76-H85, 2013.

[6] C.-F. Hung, W.-L. Chang, H.-C. Liang, and M.-J. Su, "Identification of opioid receptors in the sympathetic and parasympathetic nerves of guinea-pig atria," Fundamental \& Clinical Pharmacology, vol. 14, no. 4, pp. 387-394, 2000.

[7] C. Bolte, G. Newman, and J. E. J. Schultz, "Kappa and delta opioid receptor signaling is augmented in the failing heart," Journal of Molecular and Cellular Cardiology, vol. 47, no. 4, pp. 493-503, 2009. 
[8] T. V. Lasukova, L. N. Maslov, A. A. Platonov, N. V. Guzarova, and I. B. Lishmanov, "Role of kappal opioid receptors and cAMP in regulation of cardiac tolerance to ischemia and reperfusion," Izvestiia Akademii Nauk, no. 5, pp. 580-588, 2008.

[9] Q.-Y. Zhang, W. Wang, Q.-X. Shi et al., "Antiarrhythmic effect mediated by $\kappa$-opioid receptor is associated with Cx43 stabilization," Critical Care Medicine, vol. 38, no. 12, pp. 2365-2376, 2010.

[10] L. O. Karlsson, N. Bergh, L. Li et al., "Dose-dependent cardioprotection of enkephalin analogue Eribis peptide 94 and cardiac expression of opioid receptors in a porcine model of ischaemia and reperfusion," European Journal of Pharmacology, vol. 674, no. 2-3, pp. 378-383, 2012.

[11] A. Y. Lishmanov, L. N. Maslov, T. V. Lasukova, D. Crawford, and T. M. Wong, "Activation of $\mathrm{k}_{1}$-opioid receptor as a method for prevention of ischemic and reperfusion arrhythmias: role of protein kinase $\mathrm{C}$ and $\mathrm{K}_{A T P}$ channels," Bulletin of Experimental Biology and Medicine, vol. 143, no. 2, pp. 187-190, 2007.

[12] L. Cheng, S. Ma, L.-X. Wei et al., "Cardioprotective and antiarrhythmic effect of $\mathrm{U} 50,488 \mathrm{H}$ in ischemia/reperfusion rat heart," Heart and Vessels, vol. 22, no. 5, pp. 335-344, 2007.

[13] J.-Z. Sheng and T.-M. Wong, "Chronic U50,488H abolishes inositol 1,4,5-trisphosphate and intracellular $\mathrm{Ca}^{2+}$ elevations evoked by $\kappa$-opioid receptor in rat myocytes," European Journal of Pharmacology, vol. 307, no. 3, pp. 323-329, 1996.

[14] C.-M. Cao, Q. Xia, Y.-Y. Chen, X. Zhang, and Y.-L. Shen, “Opioid receptor-mediated effects of interleukin-2 on the $\left[\mathrm{Ca}^{2+}\right]_{i}$ transient and contraction in isolated ventricular myocytes of the rat," Pflugers Archiv European Journal of Physiology, vol. 443, no. 4, pp. 635-642, 2002.

[15] T. Kanemasa, K. Asakura, and M. Ninomiya, " $\kappa$-Opioid agonist U50488 inhibits P-type $\mathrm{Ca}^{2+}$ channels by two mechanisms," Brain Research, vol. 702, no. 1-2, pp. 207-212, 1995.

[16] B. Hassan and V. Ruiz-Velasco, "The $\kappa$-opioid receptor agonist $\mathrm{U}-50488$ blocks $\mathrm{Ca} 2+$ channels in a voltage- and G proteinindependent manner in sensory neurons," Regional Anesthesia \& Pain Medicine, vol. 38, no. 1, pp. 21-27, 2013.

[17] D. Chao and Y. Xia, "Ionic storm in hypoxic/ischemic stress: can opioid receptors subside it?" Progress in Neurobiology, vol. 90, no. 4, pp. 439-470, 2010.

[18] M. Chen, J.-J. Zhou, K. W.-L. Kam et al., "Roles of $\mathrm{K}_{\text {ATP }}$ channels in delayed cardioprotection and intracellular $\mathrm{Ca}^{2+}$ in the rat heart as revealed by kappa-opioid receptor stimulation with U50488H," British Journal of Pharmacology, vol. 140, no. 4, pp. 750-758, 2003.

[19] W. A. Macdonald, O. B. Nielsen, and T. Clausen, "Effects of calcitonin gene-related peptide on rat soleus muscle excitability: mechanisms and physiological significance," American Journal of Physiology: Regulatory Integrative and Comparative Physiology, vol. 295, no. 4, pp. R1214-R1223, 2008.

[20] K. B. Olsen, T. H. Braunstein, C. M. Sørensen, L. N. Axelsen, N. H. Holstein-Rathlou, and M. S. Nielsen, "Angiotensin II does not acutely regulate conduction velocity in rat atrial tissue," Scandinavian Journal of Clinical and Laboratory Investigation, vol. 71, no. 6, pp. 492-499, 2011.

[21] A. Pousti, T. Deemyad, G. Malihi, and K. Brumand, "A preliminary study on the interaction of fluvoxamine and adenosine receptor on isolated guinea-pig atria," International Journal of Neuroscience, vol. 116, no. 12, pp. 1491-1499, 2006.

[22] F. Speroni, A. Rebolledo, S. Salemme, M. C. Añón, F. Tanzi, and V. Milesi, "Genistein inhibits contractile force, intracellular $\mathrm{Ca}^{2+}$ increase and $\mathrm{Ca}^{2+}$ oscillations induced by serotonin in rat aortic smooth muscle," Journal of Physiology and Biochemistry, vol. 63, no. 2, pp. 143-152, 2007.

[23] A. Kovács, L. G. Hársing Jr., and G. Szénási, "Vasoconstrictor 5-HT receptors in the smooth muscle of the rat middle cerebral artery," European Journal of Pharmacology, vol. 689, no. 1-3, pp. 160-164, 2012.

[24] J. Utz, R. Eckert, and W. Trautwein, "Inhibition of L-type calcium currents in guinea pig ventricular myocytes by the $\kappa$ opioid agonist U50488h does not involve binding to opiate receptors," Journal of Pharmacology and Experimental Therapeutics, vol. 274, no. 2, pp. 627-633, 1995.

[25] T. R. L. Romero, L. S. Guzzo, and I. D. G. Duarte, "Mu, Delta, and Kappa opioid receptor agonists induce peripheral antinociception by activation of endogenous noradrenergic system," Journal of Neuroscience Research, vol. 90, no. 8, pp. 16541661, 2012.

[26] F. Niroomand, R. A. Mura, L. Piacentini, and W. Kübler, “Opioid receptor agonists activate pertussis toxin-sensitive $G$ proteins and inhibit adenylyl cyclase in canine cardiac sarcolemma," Naunyn-Schmiedeberg's Archives of Pharmacology, vol. 354, no. 5, pp. 643-649, 1996.

[27] J. E. de Menezes-Filho, A. N. Santana Gondim, J. Santos Cruz et al., "Geraniol blocks calcium and potassium channels in the mammalian myocardium: useful effects to treat arrhythmias," Basic \& Clinical Pharmacology \& Toxicology, 2014.

[28] M. Zhao, J. Zhao, G. He, X. Sun, X. Huang, and L. Hao, "Effects of astragaloside IV on action potentials and ionic currents in guinea-pig ventricular myocytes," Biological and Pharmaceutical Bulletin, vol. 36, no. 4, pp. 515-521, 2013.

[29] K. Ishihara, N. Sarai, K. Asakura, A. Noma, and S. Matsuoka, "Role of $\mathrm{Mg}_{2+}$ block of the inward rectifier $\mathrm{K}^{+}$current in cardiac repolarization reserve: a quantitative simulation," Journal of Molecular and Cellular Cardiology, vol. 47, no. 1, pp. 76-84, 2009.

[30] M. Yamada, K. Ohta, A. Niwa, N. Tsujino, T. Nakada, and M. Hirose, "Contribution of L-type $\mathrm{Ca}^{2+}$ channels to early afterdepolarizations induced by IKr and IKs channel suppression in guinea pig ventricular myocytes," Journal of Membrane Biology, vol. 222, no. 3, pp. 151-166, 2008.

[31] Y.-H. Choi, D. B. Cowan, T. C. W. Wahlers, R. Hetzer, P. J. del Nido, and C. Stamm, "Calcium sensitisation impairs diastolic relaxation in post-ischaemic myocardium: implications for the use of $\mathrm{Ca}^{2+}$ sensitising inotropes after cardiac surgery," European Journal of Cardio-Thoracic Surgery, vol. 37, no. 2, pp. 376$383,2010$.

[32] W. R. Ford, A. S. Clanachan, C. Robin Hiley, and B. I. Jugdutt, "Angiotensin II reduces infarct size and has no effect on postischaemic contractile dysfunction in isolated rat hearts," British Journal of Pharmacology, vol. 134, no. 1, pp. 38-45, 2001.

[33] T. Bragadeesh, A. R. Jayaweera, M. Pascotto et al., "Post-ischaemic myocardial dysfunction (stunning) results from myofibrillar oedema," Heart, vol. 94, no. 2, pp. 166-171, 2008.

[34] Y. Wu, J. Wan, W.-Z. Zhen et al., "The effect of butorphanol postconditioning on myocardial ischaemia reperfusion injury in rats," Interactive Cardiovascular and Thoracic Surgery, vol. 18, no. 3, pp. 308-312, 2014. 

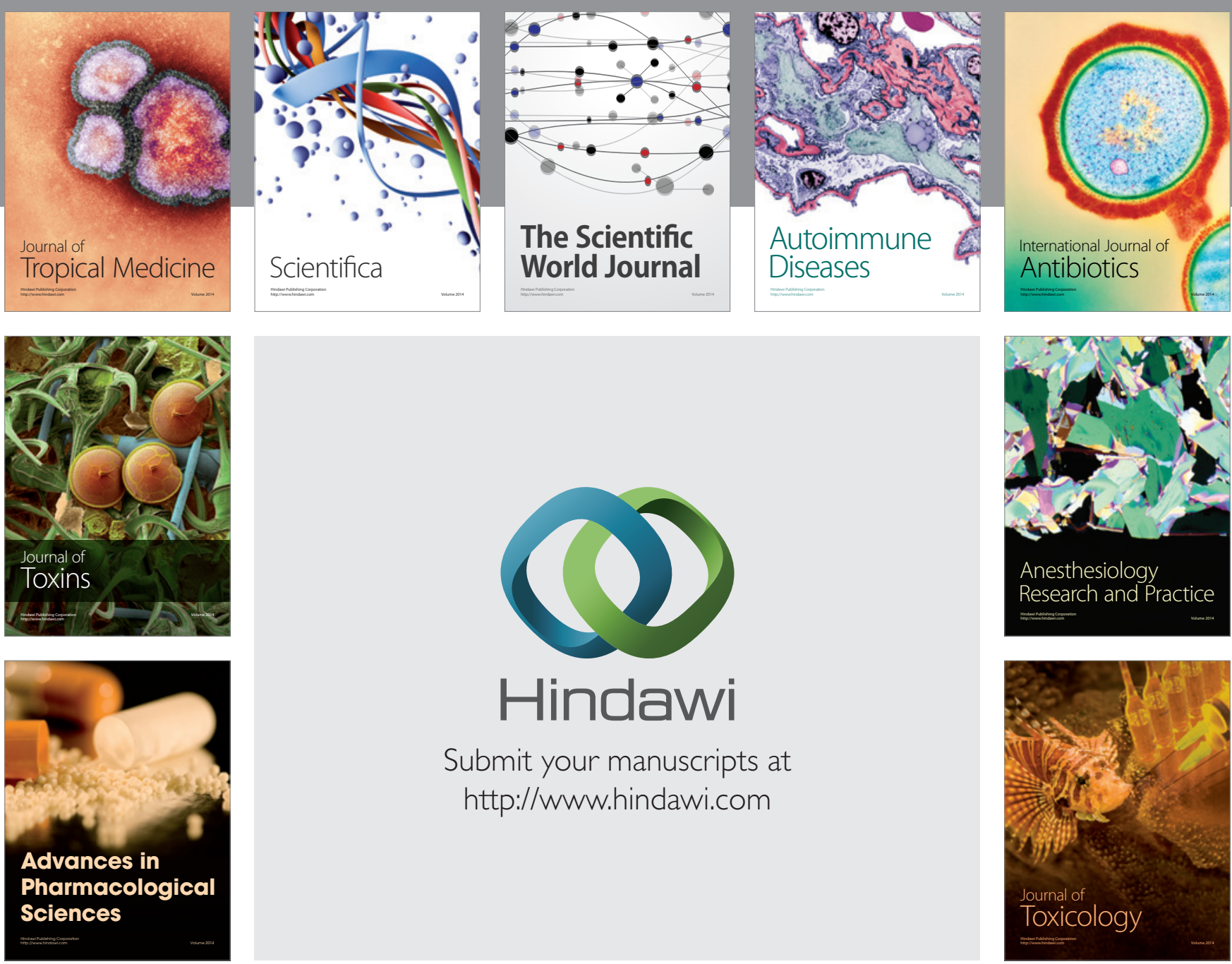

\section{Hindawi}

Submit your manuscripts at

http://www.hindawi.com
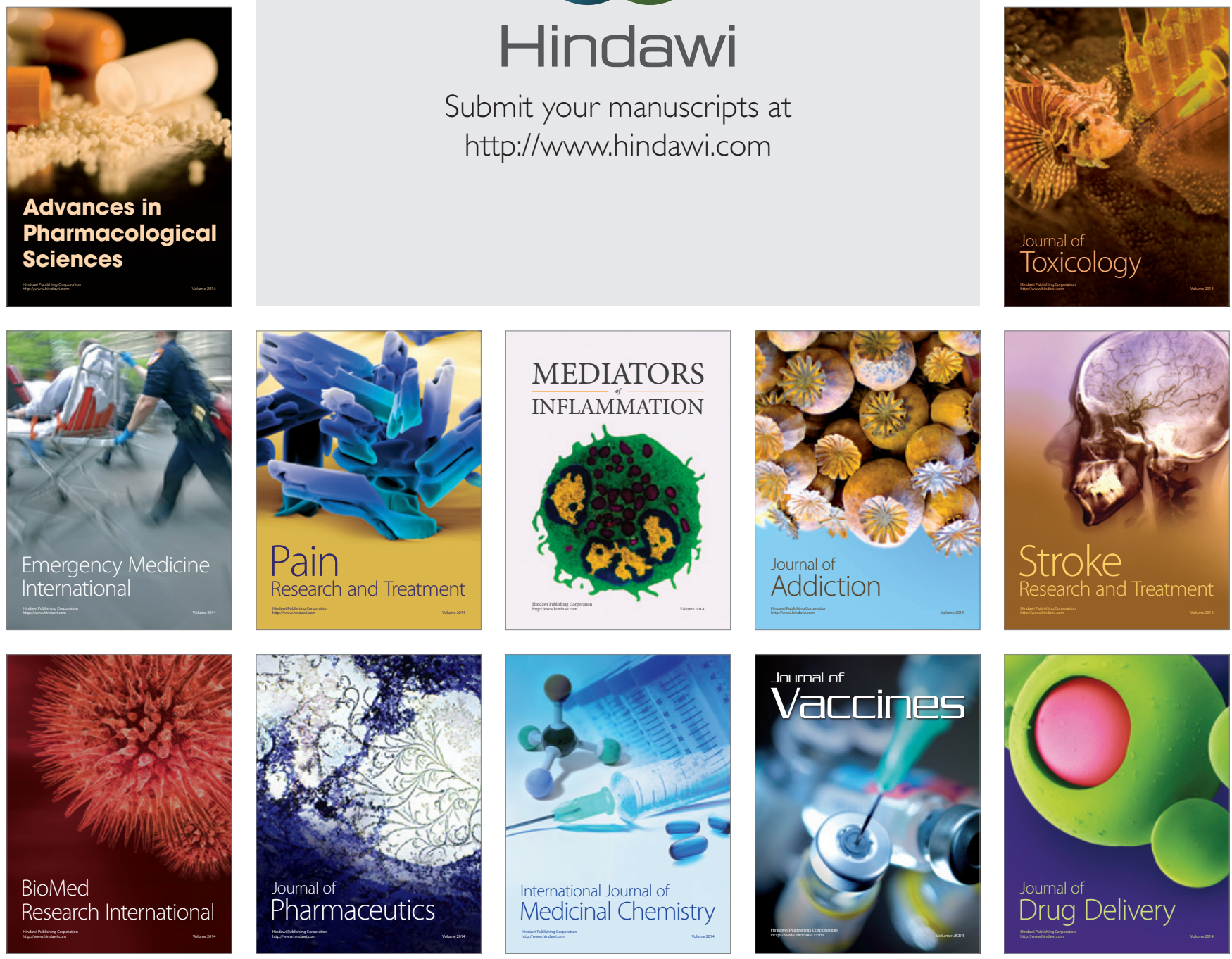